\title{
Haematological and serum biochemical indices of broiler chickens fed graded levels of inorganic and chelated trace minerals
}

${ }^{+}$Ayoola, A. A., ${ }^{+*}$ Fafiolu, A. O., ${ }^{+}$Oluwatosin, O. O., ${ }^{+\times}$Osinowo, O. A., and *Ariyo, O. W. ${ }^{+}$Centre of Excellence in Agricultural Development and Sustainable Environment, Federal University of Agriculture, Abeokuta, Ogun State Nigeria. "Animal Nutrition Department, Federal University of Agriculture, Abeokuta, Ogun State Nigeria.

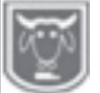
${ }^{\star}$ Agricultural Education Department, Federal College of Education, Osiele, Abeokuta Ogun State Nigeria.

Abstract

Corresponding author: remyportable@yahoo.com; +2348034935823

Poor bioavailability of inorganic trace elements used in broiler nutrition and their subsequent release into the environment via poultry excereta is major cause of biological and environmental concern. Hence, the need to explore the use of Chelated trace minerals in broiler diets. This study was carried out to evaluate the effect of supplemental inorganic and chelated $\mathrm{Cu}, \mathrm{Zn}$ and Mn on haematology and serum biochemistry of broiler chickens. A 42day feeding trial was conducted using a total of 300 Arbor acre broiler chickens. The birds were allocated to five dietary groups. Each group had six replicates containing 10 birds. The treatments were control (basal diet), 100\% inorganic trace minerals (ITMs) supplemental level (15, 100, $100 \mathrm{mg} / \mathrm{kg}$ for $\mathrm{Cu}, \mathrm{Zn}, \mathrm{Mn}$ respectively), 50\% ITMs supplemental level (7.5, $50,50 \mathrm{mg} / \mathrm{kg}$ of $\mathrm{Cu}, \mathrm{Zn}, \mathrm{Mn}$ ), 50\% Chelated trace minerals (CTMs) supplemental level (7.5, $50,50 \mathrm{mg} / \mathrm{kg}$ of $\mathrm{Cu}, \mathrm{Zn}, \mathrm{Mn}$ ) and 25\% CTM supplemental level $(3.75,25,25 \mathrm{mg} / \mathrm{kg}$ of Cu, $\mathrm{Zn}$, $\mathrm{Mn}$, in that order). A lower $(p<0.05)$ white blood cell count $\left(11.07 \times 10^{6} / \mathrm{mm}^{3}\right)$ and an improved $(p<0.05)$ red blood cell count $\left(13 \times 10^{6} / \mathrm{mm}^{3}\right)$ was observed for the group fed $50 \%$ CTM supplemental level. The group fed 50\% supplemental level of CTM had the highest $(p<0.05)$ total protein $(73.2 \mathrm{~g} / \mathrm{L})$, albumin $(41.20 \mathrm{~g} / \mathrm{L})$ and globulin $(32 \mathrm{~g} / \mathrm{L})$ in serum as compared to the other groups. The serum $\mathrm{Cu}, \mathrm{Zn}$ and Mn were significantly higher $(p<0.05)$ for the group fed $25 \%$ supplemental diet of CTM. It can be concluded that trace minerals supplementation increased serum trace minerals of broiler chicken.

Keywords: chelates, inorganic salts, haematology, serum biochemistry, broilers

\section{Introduction}

Evaluating haematological and serum biochemical parameters is a means of assessing the health status of animals and effect of treatments can be deduced from these analyses. Trace minerals are essential nutrients in broiler chicken's diets and they play very important roles in birds and these include cell proliferation and growth, tissue and bone development and integrity, immune development and response, reproduction, enzymes formation, gene regulation, and protection against oxidative stress and damage (Richards, et al., 2010). Inorganic trace minerals (ITM) of $\mathrm{Cu}, \mathrm{Zn}$ and $\mathrm{Mn}$ are often used in broiler chicken diets at the higher inclusion level than the recommended quantity by NRC (1994), but the absorption is limited due to antagonistic effects in diets and gastrointestinal tract (Manangi, et al., 2012). This results to increasing concerns over the excretion of minerals as pollutant in the environment (Manangi, et al., 2012). A chelated mineral means the bonding or combination of metal ions with organic ligand or ligand complex such as amino acids, proteinate, polysaccharides or organic yeast (Bao, et al., 2006). Therefore, this study was carried out to investigate the 


\section{Effect of inorganic and chelated minerals on the blood parameters of broiler chickens}

effect of supplemental inorganic and chelated $\mathrm{Cu}, \mathrm{Zn}$ and $\mathrm{Mn}$ on the haematology and serum biochemistry of broiler chickens.

\section{Materials and methods}

This study was carried out according to the research ethics and guidelines of the College of Animal Science and Livestock Production of the Federal University of Agriculture, Abeokuta, Nigeria. It was carried out at the broiler section (unit) of the Directorate of University Farm (DUFARM), Federal University of Agriculture, Abeokuta, Ogun State. A total of 300 unsexed day-old Arbor acre (AA) broiler chicks used for the study. The broilers were allocated to five treatments; each treatment was divided into six replicates containing 10birds, making a total of 60 birds in a treatment. The treatments were control (basal diet), 100\% inorganic trace minerals (ITMs) supplemental level $(15,100,100 \mathrm{mg} / \mathrm{kg}$ for $\mathrm{Cu}, \mathrm{Zn}, \mathrm{Mn}$ respectively), 50\% ITMs supplemental level $(7.5,50,50 \mathrm{mg} / \mathrm{kg}$ of
$\mathrm{Cu}, \mathrm{Zn}, \mathrm{Mn}), 50 \%$ Chelated trace minerals (CTMs) supplemental level (7.5, 50, 50 $\mathrm{mg} / \mathrm{kg}$ of $\mathrm{Cu}, \mathrm{Zn}, \mathrm{Mn}$ ) and $25 \% \mathrm{CTM}$ supplemental level $(3.75,25,25 \mathrm{mg} / \mathrm{kg}$ of $\mathrm{Cu}, \mathrm{Zn}, \mathrm{Mn}$, respectively). Feed and water were given ad libitum throughout the experimental period. Chelated trace minerals of $\mathrm{Cu}, \mathrm{Zn}$ and $\mathrm{Mn}$ (Mintrex ${ }^{\circledR}$ ) containing $15 \% \mathrm{Cu}$ from $\mathrm{Cu}$ (2-hydroxyl4-methylthiobutanoic acid as $\mathrm{HMTBa})_{2}$, $16 \% \mathrm{Zn}$ from $\mathrm{Zn}(\mathrm{HMTBa})_{2}$ and $13 \% \mathrm{Mn}$ from $\mathrm{Mn}(\mathrm{HMTBa})_{2}$ were obtained from Novus Inc., USA. The inorganic sources of $\mathrm{Cu}, \mathrm{Zn}$ and $\mathrm{Mn}$ were purchased from an inorganic manufacturer in Lagos. The composition of the inorganic sources used are described as follow; copper sulphate pentahydrate $\left(\mathrm{CuSO}_{4} .7 \mathrm{H}_{2} \mathrm{O}\right.$ : containing $25 \% \mathrm{Cu}$ ), zinc oxide ( $\mathrm{ZnO}$ : containing $72 \%$ $\mathrm{Zn})$ and manganese dioxide $\left(\mathrm{MnO}_{2}\right.$ : containing $64 \% \mathrm{Mn}$ ) were used as inorganic supplemental $\mathrm{Cu}, \mathrm{Zn}$ and $\mathrm{Mn}$ respectively. The five treatments diets with varying supplemental level of inorganic trace minerals (ITM) and chelated trace minerals (CTM) is shown in Table 1 .

Table 1: Gross composition of experimental basal diets

\begin{tabular}{lll}
\hline Ingredients (Kg) & $(0-3$ weeks) & $(4-6$ weeks $)$ \\
\hline Maize & 54.00 & 65.00 \\
Soya meal & 40.00 & 30.70 \\
Wheat Bran & 2.00 & 1.00 \\
Lime stone & 1.50 & 1.00 \\
Bone meal & 1.20 & 1.00 \\
Fish meal (72\% CP) & 0.50 & 0.50 \\
Methionine Hydroxyl & 0.25 & 0.20 \\
Analog & 0.20 & 0.20 \\
Lysine & 0.15 & 0.15 \\
Salt & 0.25 & 0.00 \\
Vitamin-Mineral Premix & & \\
(Cu, Zn \& Mn free) & & 0.25 \\
Vitamin-Mineral Premix & 0.00 & \\
(Cu, Zn \& Mn free) & & \\
Determined analysis & & 94.00 \\
Dry matter (\%) & 88.90 & 19.20 \\
Crude protein (\%) & 23.70 & 3054.90 \\
ME (KCal/kg) & 2946.23 & 55.6 \\
Nitrogen free extract (\%) & 47.02 & 4.48 \\
Crude fibres (\%) & 4.11 & 4.92 \\
Ether extract (\%) & 5.23 & 9.80 \\
Ash content (\%) & 8.84 &
\end{tabular}




\section{Ayoola, Fafiolu, Oluwatosin, Osinowo and Ariyo}

\section{Blood sample collection}

At day 42, 120 birds (four birds from each replicate) were bled via wing vein puncture. $2 \mathrm{~mL}$ of blood was collected from each bird using sterile syringe and needle and deposited into tubes containing ethylenediamine-tetra-acetate (EDTA) and another $2 \mathrm{~mL}$ was collected into plain sterile bottles. The blood in the EDTA bottles were used to determine haematological parameters while that in the plain bottles were used to determine serum parameters The PCV was determined by microhaematocrit method and $\mathrm{Hb}$ and $\mathrm{RBC}$ were determined using colorimetry cyanomethaemoglobin and improved Neubauer haemocytometer methods respectively. The serum total protein, albumin and globulin were analysed colorimetricaly using a diagnostic reagent kit.

\section{Statistical analysis}

Data collected were subjected to a Completely Randomized Design using SAS (2007). Comparisons among means were done using Tukey's test of the software.

\section{Results and discussion}

The effect of supplemental trace minerals on haematology are presented in Table 2.
Groups fed 50\% and 25\% supplemental level of CTM had higher $(\mathrm{p}<0.05)$ packed cell volumes $(34.67 \%$ and $33.67 \%)$ and haemoglobin $(11.33 \mathrm{~g} / \mathrm{dL}$ and $11.20 \mathrm{~g} / \mathrm{dL}$, respectively) relative to other dietary groups. Higher haemoglobin and PCV concentration in blood of broiler birds fed diets supplemented with chelated trace minerals compared to $\mathrm{BD}$ reflects the importance of $\mathrm{Cu}$ in haemoglobin synthesis. This indicates that $\mathrm{Cu}$ was more bioavailable in the CTM groups since $\mathrm{Cu}$ and $\mathrm{Fe}$ are known to play vital roles in the synthesis of haemoglobin and for the synthesis of enzyme needed for normal metabolism (Close, 1999). The white blood cell of the group fed 50\% CTM level was significantly lower $(p<0.05)$ compared to the other groups and it also had a significantly higher $(\mathrm{p}<0.05)$ red blood cell while the groups fed 100\% ITM, 50\% ITM level and BD had lower RBC. The increased $\mathrm{WBC}$ of birds given $\mathrm{BD}$ relative to those receiving CTM suggests a stimulation of the immune system by the control diet. This showed that the birds fed CTM supplemented diets with the lower WBC had immune stability and the birds were not challenged. This is in line with the report of Jegede, et al. (2011) who reported higher haemoglobin and PCV with lower WBC in broilers fed $\mathrm{Cu}$-proteinates.

Table 2: Effect of inorganic and chelated trace mineral on the haematological parameters of the experimental broiler chickens (42 days)

\begin{tabular}{llllllll}
\hline \multirow{2}{*}{ PARAMETERS } & \multicolumn{2}{c}{ Control } & \multicolumn{2}{c}{ ITM } & \multicolumn{2}{c}{ CTM } \\
\cline { 2 - 8 } & $\mathbf{( B D )}$ & $\mathbf{1 0 0} \%$ & $\mathbf{5 0 \%}$ & $\mathbf{5 0 \%}$ & $\mathbf{2 5 \%}$ & SEM & P-Value \\
\hline $\mathrm{PCV}(\%)$ & $28.50^{\mathrm{b}}$ & $31.00^{\mathrm{ab}}$ & $32.33^{\mathrm{ab}}$ & $34.67^{\mathrm{a}}$ & $33.67^{\mathrm{a}}$ & 0.66 & 0.00 \\
$\mathrm{Hb}(\mathrm{g} / \mathrm{dL})$ & $9.57^{\mathrm{b}}$ & $10.33^{\mathrm{ab}}$ & $10.67^{\mathrm{ab}}$ & $11.33^{\mathrm{a}}$ & $11.20^{\mathrm{a}}$ & 0.21 & 0.02 \\
$\mathrm{WBC}\left(10^{6} / \mathrm{mm}^{3}\right)$ & $17.97^{\mathrm{a}}$ & $17.43^{\mathrm{a}}$ & $18.67^{\mathrm{a}}$ & $11.07^{\mathrm{b}}$ & $13.90^{\mathrm{ab}}$ & 0.92 & 0.01 \\
$\mathrm{RBC}\left(10^{6} / \mathrm{mm}^{3}\right)$ & $2.42^{\mathrm{c}}$ & $2.80^{\mathrm{b}}$ & $2.89^{\mathrm{ab}}$ & $3.12^{\mathrm{a}}$ & $2.98^{\mathrm{ab}}$ & 0.07 & 0.00 \\
Neutrophil $(\%)$ & $51.00^{\mathrm{a}}$ & $26.00^{\mathrm{b}}$ & $27.33^{\mathrm{b}}$ & $15.67^{\mathrm{b}}$ & $14.00^{\mathrm{b}}$ & 3.73 & 0.00 \\
Lymphocyte (\%) & $46.00^{\mathrm{b}}$ & $70.67^{\mathrm{a}}$ & $69.00^{\mathrm{a}}$ & $80.00^{\mathrm{a}}$ & $81.33^{\mathrm{a}}$ & 3.71 & 0.00 \\
Basophil (\%) & 0.00 & 0.33 & 0.00 & 0.33 & 0.67 & 0.15 & 0.68 \\
abc Means in the same row having different superscripts are significantly different at $(\mathrm{P}<0.05)$ & &
\end{tabular}




\section{Effect of inorganic and chelated minerals on the blood parameters of broiler chickens}

The effect of supplemental trace minerals on serum biochemistry of the experimental birds is shown in Table 3. Birds fed 50\% CTM recorded the highest $(\mathrm{p}<0.05)$ total protein value $(73.2 \mathrm{~g} / \mathrm{L})$, albumin $(41.20 \mathrm{~g} / \mathrm{L})$ and globulin $(32 \mathrm{~g} / \mathrm{L})$ in serum as compared to other groups with the group fed $100 \%$ ITM level having the lowest $(\mathrm{p}<0.05)$ serum protein of $62.53 \mathrm{~g} / \mathrm{L}$. Also, the group fed BD had a significantly lower $(\mathrm{p}<0.05)$ albumin $(35.77 \mathrm{~g} / \mathrm{L})$ compared with $41.2 \mathrm{~g} / \mathrm{L}$ of the group fed $50 \%$ supplemental diet of CTM. The serum $\mathrm{Cu}(16.5 \mathrm{ug} / \mathrm{dL}), \mathrm{Zn}(14.13 \mathrm{ug} / \mathrm{dL})$ and $\mathrm{Mn}$ $(1.88 \mathrm{ug} / \mathrm{dL})$ were significantly higher $(p<0.05)$ for the group fed $25 \%$ CTM compared to the group fed $100 \%$ supplemental ITM level with 15.08, 11.03, and $1.61 \mathrm{ug} / \mathrm{dL}$ of serum $\mathrm{Cu}, \mathrm{Zn}$ and $\mathrm{Mn}$ respectively while the group fed $\mathrm{BD}$ had the lowest $(\mathrm{p}<0.05) \mathrm{Cu}, \mathrm{Zn}$ and $\mathrm{Mn}$ in the serum. The improvement in total protein, serum albumin and globulin in groups fed diet supplemented with CTM as a result of the supplemented methionine hydroxyl analog (MHA) chelated with trace minerals compared to the groups fed diet supplemented with ITM. The higher serum protein, albumin and globulin showed that the MHA or 2- hydroxyl -4- methyl thiobutanoic acid (HMTBa) which is regarded as precursor of DL- methionine (first limiting amino acid) (Richards, et al., 2007) were released from the ligand. Copper is also involved in blood proteins and has capacity to influence serum protein (Uany, et al., 1998) This observation is supported by Corzo, et al. (2009) who reported that supplemental amino acid (valine and isoleucine) in broiler chicken diet increased the serum protein, albumin and globulin. The increased serum $\mathrm{Cu}, \mathrm{Zn}$ and $\mathrm{Mn}$ of the groups fed supplemental diet of CTM compared with the groups fed ITM level and $\mathrm{BD}$ with lower serum minerals indicates that the CTM were more bioavailable to the broiler chickens and this also shows that there is less antagonism with other dietary minerals and among themselves. This study agrees with the report of Salami, et al. (2016) who reported higher bioavailability of trace mineral from mineral chelates and less antagonistic interaction of chelates with other dietary constituents in the digestive tract compared with inorganic salts.

Table 3: Effect of inorganic and chelated trace minerals of serum biochemistry of the experimental broiler chickens (42 days)

\begin{tabular}{|c|c|c|c|c|c|c|c|}
\hline PARAMETERS & Control & ITM & & СТM & & & \\
\hline & (BD) & $100 \%$ & $50 \%$ & $50 \%$ & $25 \%$ & SEM & P-Value \\
\hline $\mathrm{TP}(\mathrm{g} / \mathrm{L})$ & $65.90^{\mathrm{c}}$ & $62.53^{\mathrm{d}}$ & $67.00^{\mathrm{bc}}$ & $73.20^{\mathrm{a}}$ & $69.87^{\mathrm{b}}$ & 0.99 & 0.00 \\
\hline Albumin $(\mathrm{g} / \mathrm{L})$ & $35.77^{\mathrm{c}}$ & $36.67^{\mathrm{bc}}$ & $38.30^{\mathrm{bc}}$ & $41.20^{\mathrm{a}}$ & $39.73^{\mathrm{ab}}$ & 0.60 & 0.00 \\
\hline Globulin $(\mathrm{g} / \mathrm{L})$ & $30.27^{\mathrm{ab}}$ & $25.87^{\mathrm{c}}$ & $28.70^{\mathrm{b}}$ & $32.00^{\mathrm{a}}$ & $30.13^{\mathrm{ab}}$ & 0.58 & 0.00 \\
\hline $\begin{array}{l}\text { Creatinine } \\
(\mathrm{mg} / \mathrm{dL})\end{array}$ & 0.77 & 1.40 & 1.27 & 0.87 & 1.43 & 0.11 & 0.17 \\
\hline Uric (mg/dL) & 5.80 & 8.57 & 8.33 & 7.93 & 7.60 & 0.41 & 0.21 \\
\hline $\begin{array}{l}\text { Serum Cu } \\
(\mathrm{ug} / \mathrm{dL})\end{array}$ & $6.77^{c}$ & $15.08^{\mathrm{b}}$ & $15.53^{\mathrm{b}}$ & $16.17^{\mathrm{a}}$ & $16.50^{\mathrm{a}}$ & 0.97 & 0.00 \\
\hline $\begin{array}{l}\text { Serum Zn } \\
(\mathrm{ug} / \mathrm{dL})\end{array}$ & $4.05^{\mathrm{e}}$ & $11.03^{\mathrm{d}}$ & $12.80^{\mathrm{c}}$ & $13.53^{\mathrm{b}}$ & $14.13^{\mathrm{a}}$ & 0.98 & 0.00 \\
\hline
\end{tabular}


Ayoola, Fafiolu, Oluwatosin, Osinowo and Ariyo

\section{Conclusion}

The study indicated that trace mineral supplementation increased serum trace mineral concentration. Supplementation of $\mathrm{CTM}(\mathrm{Cu}, \mathrm{Zn}$ and $\mathrm{Mn})$ at $50 \%$ improved oxygen transportation to the cells and blood viscosity of broiler chickens.

\section{Acknowledgements}

The Authors will like to thank the Centre of Excellence in Agricultural Development and Sustainable Environment, Nigeria (CEADESE-FUNAAB) and Novus Inc., USA for their financial support.

\section{References}

Bao, Y. M., Choct, M., Iji, P. A. and Bruerton, K. 2006. Broiler chickens could benefit from organically complexed copper, iron, manganese and zinc. Proceedings of the $18^{\text {th }}$ Australian Poultry Science. Symposium, Sydney, Australia, February 20-22, pp. $222-225$.

Close, W. H. 1999. Biotechnology in the feed Industry. Proceedings of Alltech's $15^{\text {th }}$ Annual Symposium, 51-55.

Corzo, A., Schilling, M. W., Loar II, R. E., Jackson, V., Kin, S. and Radhakrishnan, V. 2009. The feeding distillers dried grains with solubles on broiler meat quality. Poultry Science. 88(2):432-439
Jegede, A. V., Oduguwa, O. O., Bamgbose, A. M., Fanimo, A. O. and Nollet, L. 2011. Growth response, blood characteristics and $\mathrm{Cu}$ accumulation in organs of broilers fed on diets supplemented with organic and inorganic dietary $\mathrm{Cu}$ sources. British Poultry Science. 52:133-139

Manangi, M. K., Vazquez-Añon, M., Richards, J. D., Carter, S., Buresh, R. E. and Christense, $K$. D. 2012. Impact of feeding lower levels of chelated trace minerals versus industry levels of inorganic trace minerals on broiler performance. Journal of Applied Poultry Resources, 21:881-890

Richards, J. D., Zhao, J., Harrell, R. J., Atwell, C. A. and Dibner, J. J. 2010. Trace mineral nutrition in poultry and swine. AsianAustralian Journal of Animal Sciences, 23:1527-1534.

Salami, S. A., Oluwatosin, O. O., Oso, A. O., Fafiolu, A. O., Jegede, A. V., Adeleye, O. O. and Sogunle, $O$. M. 2016. Growth, mineral bioavailability and bone quality of turkeys fed inorganic blends or mineral chelates of $\mathrm{Cu}, \mathrm{Zn}$ and $\mathrm{Mn}$. Tropical Agriculture. (Trinidad), 93(4):258-270.

Uany, R., Olivares, M. and Gonzales, $M$. 1998. Essentiality of copper in humans. American Journal of Clinical Nutrition. 67(5):952-959.

Received: $12^{\text {th }}$ September, 2019 Accepted: $19^{\text {th }}$ February, 2020 